\title{
Smart Taxes: An Open Invitation to Join the Pigou Club
}

\section{Citation}

Mankiw, N. Gregory. 2009. Smart taxes: An open invitation to join the Pigou club. Eastern Economic Journal 35(1): 14-23.

\section{Published Version}

doi:10.1057/eej.2008.43

\section{Permanent link}

http://nrs.harvard.edu/urn-3:HUL.InstRepos:4263740

\section{Terms of Use}

This article was downloaded from Harvard University's DASH repository, and is made available under the terms and conditions applicable to Open Access Policy Articles, as set forth at http:// nrs.harvard.edu/urn-3:HUL.InstRepos:dash.current.terms-of-use\#OAP

\section{Share Your Story}

The Harvard community has made this article openly available.

Please share how this access benefits you. Submit a story.

Accessibility 


\title{
Smart Taxes: An Open Invitation to Join the Pigou Club
}

\author{
By N. Gregory Mankiw \\ Harvard University
}

\begin{abstract}
Many economists favor higher taxes on energy-related products such as gasoline, while the general public is more skeptical. This essay discusses various aspects of this policy debate. It focuses, in particular, on the use of these taxes to correct for various externalities — an idea advocated long ago by British economist Arthur Pigou.
\end{abstract}

Based on a talk presented at the Eastern Economic Association, March 8, 2008. 
As an economics educator, I have always been fascinated by topics about which there is a large gap between the beliefs of economists and those of the general public. For example, economists are generally supportive of free trade among nations, while the public is more skeptical. Economists oppose rent control, while much of the public supports the policy.

In these and other cases where economists and mere muggles don’t see eye-toeye, you shouldn’t be surprised to hear that I am quick to side with my fellow economists. I like to think that this reaction is more than mere professional solidarity but is, instead, a symptom of my commitment to rational thought. Unlike most people, who spend their time thinking about their children, local sports team, or favorite sitcom, economists have devoted much of their lives to thinking about such things as international trade and rent control. That fact may make us boring at cocktail parties, but it does have some offsetting benefits. It is not a stretch to believe that more thought about an issue leads to more reliable conclusions. As a result, I feel comfortable with conclusion that, regarding these issues, economists are right and the general public is just ill informed.

My topic for today is a policy about which there is a particularly large gap between economists and the public: Pigovian taxation. In particular, I want to talk about taxes on energy-related products, such as gasoline taxes. Not long ago, the economist 
Steve Levitt, coauthor of the best-seller Freakonomics, wrote on his blog, "For a long time I have felt the price of gasoline in the United States was way too low. Pretty much all economists believe this.” Levitt then went on to argue for higher taxes on gasoline. At about the same time, Speaker of the House Nancy Pelosi had precisely the opposite perspective. She announced "a series of hearings to address rising gas prices—focusing on the causes, the burdens they put on American families and businesses, and solutions.”

Both Levitt and Pelosi represent beliefs that are widespread among their respective constituencies. Let's start with the economists. In a 2006 survey of $\mathrm{PhD}$ members of the American Economic Association, 65.0 percent agreed that "the U.S. should increase energy taxes." (Whaples 2006) Similarly, the Wall Street Journal asked business economists in 2007, "What is the most economically sound way for the government to encourage development of alternatives to fossil fuels?” The poll found 54 percent advocating "taxes that raise the cost of purchasing fossil fuels." (Izzo 2007) Levitt may overstate things when he said all economists favor higher taxes on gasoline, but he is right that a majority do.

Compare these results to a Wall Street Journal poll of the general public. The Journal found that "a majority of Americans believe it is important to reduce the energy consumption from automobile use.” But how did they want to do this? The Journal reported that " $79 \%$ of respondents said encouraging the development and use of alternative fuels is important and $73 \%$ said it is important to increase fuel efficiency standards on all vehicles. Only 5\% of those polled said they support creating a tax on 
driving.” (Bright 2007) In the face of these numbers, it is no surprise that our political leaders such as Nancy Pelosi generally avoid talk of higher energy taxes.

In a democracy, of course, economic policy is set not by economists but by the general public. One of my favorite books of recent years is Bryan Caplan's treatise The Myth of the Rational Voter, subtitled Why Democracies Choose Bad Policies. The answer Caplan offers is that voters are worse than ignorant about basic economic principles of good policy. Ignorance, at least, would have the virtue of being random and so perhaps would average out to zero in a large population. Instead of being merely ignorant, voters hold onto systematically mistaken beliefs. And politicians, whose main job is to get elected, mold those mistaken beliefs into bad public policy. To quote Caplan, "What happens if fully rational politicians compete for the support of irrational voters-specifically, voters with irrational beliefs about the effects of various policies? It is a recipe for mendacity.”

The Caplan thesis goes a long way toward explaining current public policy regarding Pigovian taxation. I believe that most politicians understand the arguments for higher taxes on gasoline and other energy products and are often privately convinced by them. But they also know that the general public is not convinced, and so they feign opposition. I am confident, however, that if the public were ever to change its mind on the matter, our political leaders would quickly follow suit.

What I would like to do here is to make the case for increased use of Pigovian taxation. If you are a person skeptical of higher gasoline and energy taxes, you are the 
person I am trying to convince. If you are someone who already agrees with me, I hope to arm you with some arguments you can use to convince your fellow citizens. For believers in Pigovian taxation such as myself, the primary task ahead is one of education. To many economists, the basic argument for increased use of Pigovian taxes is so straightforward as to be obvious. But as George Orwell once put it, "We have now sunk to a depth where the restatement of the obvious is the first duty of intelligent men.”

\section{Market Efficiency and Corrective Taxes}

One big lesson of basic microeconomics is that under certain conditions, markets allocate resources efficiently. I think of this as the magic of Adam Smith’s invisible hand. In more advanced courses in economics, the efficiency of market outcomes is derived with extraordinary rigor, and it is called the "first fundamental theorem of welfare economics.”

The job of economic theorists is to prove theorems. The job of policy economists is to figure out which theorems to apply. All theorems are based on axioms, so when applying any theorem to the world, one has to evaluate whether the axioms assumed by the theorem are valid. In the case of the fundamental welfare theorem, one key axiom is the absence of externalities. If an economic transaction imposes costs or benefits on individuals who are not part of the transaction, this theorem will not apply, and Adam Smith's invisible hand will fail to lead to an efficient outcome. This is a key lesson taught in introductory economics courses. 
There is, however, a simple way to remedy the market failure and restore the optimality properties from the fundamental welfare theorem: Individuals can be charged for the external costs they impose on others (and subsidized for the external benefits they give to others). The solution goes back to Arthur Pigou, the British economist from the early $20^{\text {th }}$ century, who was sometimes friend and sometime nemesis to his more famous colleague John Maynard Keynes. In his honor, these corrective measures are called Pigovian taxes.

For at least two reasons, Pigovian taxes are popular among economists. First, they are often the least invasive way to remedy a market failure. They can restore an efficient allocation of resources without requiring a heavy-handed government intervention into the specific decisions made by households and firms. Second, they raise revenue that the government can use to reduce other taxes, such as income taxes, which distort incentives and cause deadweight losses.

\section{Carbon Emissions and Global Warming}

The debate over global warming provides a good case study illustrating these general points, and it makes the theoretical case for Pigovian taxes, while not new to economists, particularly timely in the current debate over public policy. I take it as the scientific consensus that the earth is getting warmer and that human emissions of carbon into the atmosphere are the main cause of this trend. I understand that some people 
dispute this conclusion, but I want to avoid that debate. As an economist, I don't have a comparative advantage in evaluating these scientific arguments. Instead, I will take the current scientific consensus, as I understand it, as my starting point in order to focus on the possible policy responses.

The economics here is straightforward: Emitting carbon into the atmosphere entails a negative externality. Absent any policy, people will emit too much. The Pigovian policy response is to impose a tax on carbon emission. This will induce households and firms to internalize the carbon externality when deciding, for example, how much to drive, what kind of car to buy, how much electricity to use, what kind of electric power plant to build, and so on.

The hard part of the problem is figuring out what size tax is appropriate. The right tax would equal the size of the external cost of carbon emission—-that much is clear. Unfortunately, there is little consensus about how large that external cost is. One of the most prominent economists studying this topic is Yale’s Bill Nordhaus. Nordhaus (2007) has suggested a tax of $\$ 30$ per ton of carbon, increasing to about $\$ 85$ in 2050. A $\$ 30$ carbon tax is fairly modest in size: It would increase the price of gasoline by only about 8 cents per gallon.

By contrast, the economist Nicholas Stern (2006) reached a very different conclusion in a study prominently released by the British government. Stern estimates 
the external cost of carbon emission at over \$300 per ton-more than ten times the Nordhaus number.

Part of the disagreement arises from the question of how one should discount the distant future. To see why the discount rate matters so much, let me give you a simple numerical example. Suppose I were to tell you that some event-it could be global warming, or it could be a falling meteor-is going to lower permanently real GDP by $\$ 100$ billion dollars starting one century from now. How much would you pay today to avoid that future event? The answer depends on how you trade off dollars today against dollars in the future, which is measured by the discount rate. At a discount rate of 1 percent per year, you would be willing to pay $\$ 3.7$ trillion today. At a discount rate of 5 percent per year, the answer is a mere $\$ 15$ billion. Plausible changes in the rate of discount can easily change the answer by more than 100 -fold. This simple numerical example goes to the heart of a difficult problem: The issue of global warming involves taking costly actions today to avoid adverse outcomes that will occur far in the future. Economists have not yet figured out the best way to calibrate that tradeoff.

So while Nordhaus and Stern would probably agree that a carbon tax is the right policy for dealing with the problem, they would have trouble reaching agreement about its size. But that is, at least, the right debate to be having. Discussing the size of a carbon tax, rather than alternatives to it, would be a big step forward compared to where the public discussion is right now. 


\section{Alternatives to the Carbon Tax}

But let me now take a look at the alternatives. The case for a carbon tax looks even stronger after examining the other options on the table.

Let's start with CAFE standards. CAFE here is not a cute French bistro, but rather Corporate Average Fuel Economy. In essence, lawmakers in both political parties want to require carmakers to increase the fuel efficiency of the cars they sell. It is easy to see why passing the buck to auto companies has a lot of popular appeal.

Increased fuel efficiency, however, is not free. Like a tax, the cost of complying with more stringent regulation will be passed on to consumers in the form of higher car prices. But, unlike a tax, the government will not raise any revenue that it can use to reduce other taxes to compensate for these higher prices. (And don’t expect savings on gas to compensate consumers in a meaningful way: Any privately cost-effective increases in fuel efficiency would already have been made. The whole purpose of CAFE standards is to require increased efficiency beyond what is privately optimal.)

More important, enhancing fuel efficiency by itself is not the best way to reduce energy consumption. Fuel use depends not only on the efficiency of the car fleet but also on the daily decisions that people make — how far from work they choose to live and how often they carpool or use public transportation.

A carbon tax would provide incentives for people to use less fuel in a multitude of ways. By contrast, merely having more efficient cars encourages more driving. Increased 
driving offsets some of the direct carbon benefit of more having more efficient cars. It also exacerbates other problems, such as accidents and road congestion.

Another popular proposal to limit carbon emissions is a cap-and-trade system, under which carbon emissions are limited and allowances are bought and sold in the marketplace. The effect of such a system depends on how the carbon allowances are allocated. If the government auctions them off, the price of a carbon allowance is effectively a carbon tax. I should note that both Barack Obama and John McCain have at times endorsed auctioning permits under a cap-and-trade system, although neither has made it a prominent part of his campaign, no doubt heeding the sound advice of political advisers.

Unfortunately, the history of cap-and-trade systems for other pollutants suggests that the carbon allowances would probably not be auctioned. Instead, they would be handed out to power companies and other carbon emitters, which would then be free to use them or sell them at market prices. In this case, the prices of energy products would rise as they would under a carbon tax, but the government would collect no revenue to reduce other taxes and compensate consumers.

The problem with such cap-and-trade programs is that they, in essence, give the revenue from a Pigovian tax lump-sum to a regulated entity. Why should an electric utility, for example, be given a valuable resource simply because it has for years polluted the environment? That does not strike me as equitable. A new firm entering the market should not have to pay for something that an incumbent gets for free. And the fact that the incumbent has for years been taking a valuable resource from the rest of society is no 
reason to think it deserves a free ride in the future. On equity grounds, one could just as easily argue that the incumbents should compensate society for their past misdeeds.

Cap-and-trade systems are also relatively inefficient, for three reasons. First, if pollution rights are allocated based on historical emissions, the prospect of a cap-andtrade system encourages utilities to pollute more before the system is put into effect in order to "earn" pollution rights. Second, unless pollution rights are fully auctioned, they waste the opportunity to use the Pigovian tax revenue to reduce distortionary taxes on labor and capital. Third, if the demand for carbon emissions fluctuates from year to year because of, for example, the business cycle, the price of a pollution permit and thus the marginal cost of abatement would fluctuate over time. Because global warming depends only on the sum of carbon emissions over time, the cost-minimizing path is to smooth the price of emissions and to allow the quantity to fluctuate. That efficient dynamic path is more easily achieved with a Pigovian tax on carbon emissions.

Of course, cap-and-trade systems are better than heavy-handed regulatory systems. But they are not as desirable, in my view, as Pigovian taxes coupled with reductions in other taxes.

\section{International Dimensions of the Problem}

The international dimension of the problem also suggests the superiority of a carbon tax over cap-and-trade. Any long-term approach to global climate change will have to deal with the emerging economies of China and India. By some reports, China is now the world's leading emitter of carbon, in large part simply because it has so many 
people. The failure of the Kyoto treaty to include these emerging economies is one reason why, in 1997, the United State Senate passed a resolution rejecting the Kyoto approach by a vote of 95 to zero.

Agreement on a truly global cap-and-trade system, however, is hard to imagine. Think about how the allowances would be allocated between, say, China and the United States. China is unlikely to be persuaded to accept fewer carbon allowances per person than the United States. Using a historical baseline to allocate allowances, as is often proposed, would reward the United States for having been a leading cause of the problem. China is never going to agree to that.

But allocating carbon allowances based on population alone would create a system in which the United States, with its higher standard of living, would buy allowances from China. American voters are not going to embrace a system of higher energy prices, coupled with a large transfer of national income to the Chinese. Such a system would amount to a massive foreign aid program to one of the world's most rapidly growing economies.

A global carbon tax would be much easier to negotiate. All governments require revenue for public purposes. The world's nations could agree to use a carbon tax as one instrument to raise some of that revenue. No money need change hands across national borders. Each government could keep the revenue from its tax and use it to finance spending or whatever form of tax relief it considered best. 


\section{Related Externalities}

So far, I have been talking about global climate change and the case for a carbon tax. I know that some people are skeptical about global warming, and if you are, I am certainly not enough of a scientist to convince you otherwise. I will leave that job to $\mathrm{Al}$ Gore. But the case for higher Pigovian taxes is based on more than the conclusion of that particular debate.

Let me focus on the activity of driving - an activity that takes a sizeable fraction of the average American’s waking hours. This activity has a large number of external costs. One of them is carbon emissions, as I have been discussing. Another is local pollution, such as smog.

A third external cost is congestion. Every time I am stuck in traffic, I wish my fellow motorists would drive less, perhaps by living closer to where they work or by taking public transport. And they might well be thinking the same about me. In essence, each of us is imposing external costs on everyone else.

A fourth external cost is accidents and the higher insurance rates we all pay. That is, when I choose to drive, I make it more likely that I will be in an accident. That is, of course, an internal cost that I fully take into account when deciding whether to take my car out of the garage. But, in addition, when I drive, I make it more likely that you will be in an accident. That is an external cost, which from an economic standpoint is equivalent to pollution. The numbers here are staggering. According to the U.S. 
National Highway Traffic Safety Administration, there are more than 30 million traffic accidents a year. It estimates that the annual dollar cost of accidents, including property damage and personal injury, amounts to more than $\$ 400$ billion a year.

There is a large literature that tries to put numbers on each of these external costs of driving. An article published in the Journal of Economic Literature in June 2007 summarized the many studies and concluded that the optimal Pigovian tax on gasoline was $\$ 2.10$ per gallon. (Parry, Walls, and Harrington 2007) That is well above the current level of taxation in the United States, which is about 40 cents a gallon.

Such a huge increase in the gasoline tax may seem unrealistic to you, but international experience suggests that it is in fact a plausible public policy. Other nations, such as Japan and Ireland, have gas taxes at about the \$2 level suggested in the study. And other nations, such as Germany and England, have gas taxes about \$3 a gallon. The United States is very much an outlier in how little we tax gasoline.

Let’s look a little deeper at that $\$ 2.10$ figure. Only about 6 cents of that amount came from the external effects associated with global warming. Most of it came from the more mundane externalities. The largest, making up half of the total external cost, was from congestion. The second largest was from accidents. So even if God came down today and told us that global warming was a complete hoax, the case for a much higher Pigovian tax on gasoline would survive, for the simple reason that every time you get in 
your car and drive, you inconvenience other drivers with increased road congestion and you put them at increased risk of being in a traffic accident.

I should note that a gasoline tax is an imperfect instrument for dealing with externalities such as congestion. One problem is that some roads are more congested than others, and congestion varies by time of day. An ideal Pigovian tax to deal with congestion externalities would adjust the tax to driving conditions. That is not as crazy as it sounds. The city of London has instituted a fee for driving in the most congested part of the city. The idea was pushed by Mayor Ken Livingstone. Livingstone is so leftleaning politically that he has been nicknamed "Red Ken.” Livingstone says, however, that he got the idea of congestion pricing from the renowned free-market economist Milton Friedman. New York mayor Michael Bloomberg has recently proposed a similar plan for his city.

\section{Energy Independence}

There is one argument that you sometimes hear for higher gasoline taxes that I should probably comment on —-that it would help us achieve the goal of "energy independence.” Politicians from both political parties often proclaim the importance of energy independence as a policy goal, and such proclamations win easy applause from crowds. But they often leave economists scratching their heads.

Without doubt, it would be great if we could wave a magic wand and costlessly reduce the need for imported energy. And, indeed, calls for energy independence are 
usually followed by magic-wand-like claims about what conservation or technological advance is likely to produce. But if we don’t have a magic wand, and I don’t think we do, what does it mean to call for energy independence? Another word for "independence" is "autarky." If free trade is in general good for a nation, the same set of arguments should apply to energy products.

A related, and perhaps more coherent, argument is that we need to reduce our use of foreign oil for reasons of national security. Many prominent policymakers, including former Fed chairman Alan Greenspan, former Secretary of State George Schultz, and former national security adviser Tony Lake have called for increased taxes on gasoline on national security grounds. Maybe there is a good Pigovian argument related to national security, but as it involves the complicated dynamics of world politics, this argument is hard for an economist to evaluate. But I should note that even if a higher gasoline tax reduced our consumption of oil, we could not decouple our economy from turmoil in the Middle East. The price of oil is set in a world market, and that is true regardless of how much or how little we use. It is hard is escape the fact that American consumers are going to be subject to price volatility arising in other parts of the world.

\section{The Question of Incidence}

Let me turn to another reason why the United States might consider a higher tax on oil, beyond the Pigovian arguments I have been making so far. Another, completely unrelated argument involves the basic theory of tax incidence. 
So far, I have presumed that the burden of these taxes would be fully borne by consumers. That would be true if the United States were a small country. If this were the case, the world price of oil would not depend on our tax policies.

But the United States is a big oil consumer - in fact, we use almost a quarter of the world's production. As a result, we have substantial market power. Our tax policies can have a significant impact on the world price of oil. This means that, in the long run, part of a U.S. gasoline tax gets paid by the producers of oil, not the consumers. This is an example of what economists call the optimal tariff argument.

Many years ago, the economist Ted Bergstrom (1982) did some calculations trying to estimate optimal tax policy if oil-consuming nations wanted to transfer more OPEC profits to themselves. According to Bergstrom, if each nation pursued a policy on its own (so we get what game theorists call the Nash equilibrium), gas taxes in Europe should be somewhat lower, and gas taxes in the United States should be much higher. If, however, the United States, Europe and Japan all coordinated their policies, so we could reach a cooperative equilibrium, we should all tax oil at a rate of 100 to 200 percent. That would amount to several dollars a gallon of gasoline, compared to about 40 cents now.

This is, without doubt, a sizeable tax hike. I should point out that prices at the pump would rise by much less than the amount of the tax increase, because reduced 
consumption would lower world oil prices. That indeed is the point of the policy: to collect some revenue from OPEC.

As long as I am speaking about incidence and OPEC, let me note a couple of arguments that one hears about this topic. Sometimes, when the world price of oil rises, as it has done recently, commentators say that this is a good thing. They claim, in essence, the price increase is equivalent to the optimal Pigovian tax. This argument is, in my view, more wrong than right. An increase in world oil prices is like a tax on oil, where the revenue from the tax is handed over to world suppliers of oil. I would be a lot less supportive of a Pigovian tax on gasoline if the Congress were going to hand the tax revenue over to the Saudis. I am eager for this tax only if the revenue is to be used to reduce other taxes, either contemporaneously or in the future.

Another argument you sometimes hear when the world price of oil rises is that Congress should protect consumers from these shocks by suspending gas taxes until world oil prices return to normal. This is a poor idea for a couple reasons. First, the tax is already too low, for the reasons I have been describing. Second, think about how this policy response would affect the incentives facing OPEC. Lowering the gas tax as the world price rises reduces the response of U.S. oil consumption to higher world prices. In other words, it makes the effective demand curve less elastic. With a less elastic demand curve, OPEC would have even more market power than it already has, and it would jack up the price even higher. 


\section{Distribution Effects}

While I am on the topic of who pays, let me try to dispel a common fear about higher Pigovian taxes, such as taxes on carbon or gasoline--that they will fall disproportionately on the poor. Certainly, a gasoline tax would, by itself, raise the tax burden on anyone who drives a car. And a carbon tax would, in addition, raise the tax burden on anyone who uses electricity produced with fossil fuels, which includes just about everybody. Some might fear these taxes would be particularly hard on those at the bottom of the economic ladder.

Yet that is not necessarily the case. A 1991 study by MIT economist James Poterba called "Is the Gasoline Tax Regressive?" concluded that "low-expenditure households devote a smaller share of their budget to gasoline than do their counterparts in the middle of the expenditure distribution." The poor are far more likely than higherincome households to ride the bus or subway to work.

Moreover, if Congress were to use a hike in Pigovian taxes to pay for a cut in other taxes, there is nothing to stop it from cutting tax rates on lower incomes more than on higher incomes. Gilbert Metcalf, an economist at Tufts, has shown how revenue from a carbon tax could be used to reduce payroll taxes in a way that would leave the distribution of total tax burden approximately unchanged. He proposes a tax of \$15 per metric ton of carbon dioxide, together with a rebate of the federal payroll tax on the first $\$ 3,660$ of earnings for each worker. (Note that $\$ 15$ per ton of carbon dioxide is equivalent to $\$ 55$ per ton of carbon.) 
So while it makes sense to think through the distributional impact of higher gasoline or carbon taxes, concern about the income distribution need not be a reason to avoid these taxes. The economists in the Treasury department are fully capable of designing a package of tax hikes and tax cuts that together internalize externalities and leave the overall distribution of the tax burden approximately unchanged.

\section{Not a Wacky Idea}

In my introduction, I mentioned Speaker of the House Nancy Pelosi as an example of a political leader expressing concern about high gas prices. Perhaps, to be fair, I should have pointed out that political opposition to higher gas taxes is bipartisan, and if anything, is perhaps a bit stronger among Republicans than Democrats. Bill Clinton did propose a BTU tax in 1993, but the plan died in Congress. The political fallout from that wise but ill-fated attempt may be one reason why so many elected leaders are now reluctant to try again.

When I was chairman of President Bush's Council of Economic Advisers, I once raised the topic of an increased gasoline tax as I sat in the oval office in the midst of a discussion of reforming CAFE standards. The president made pretty clear that he thought higher gasoline taxes were a wacky idea. And, in fact, during the 2004 campaign, the Bush team ran a television ad criticizing John Kerry for once favoring a 50 cent increase in the gas tax. "Some people have wacky ideas," the voiceover said. 
As judged on purely political terms, higher Pigovian taxes are a wacky idea. I have yet to see a major candidate for President endorse the concept. In 2004, John Kerry denied being in favor of high gas taxes. His campaign said that it was Bush adviser Greg Mankiw who in fact favored high gas taxes. That retort was correct-I had written in favor of higher gasoline taxes several times. But it was not particularly effective: Few voters had any idea who Greg Mankiw was.

As judged by the standard principles of economics, however, rather than by the standards of politics, higher Pigovian taxes are not wacky but eminently sensible. My goal here has been to convince you of that view. Only you can judge if I have succeeded. If so, and if we together can convince enough other voters, the political dynamic will undoubtedly change. We can hope that in future elections the gap between the advice of the economic advisers and the advice of the political consultants will become a lot smaller. 


\section{References}

Bergstrom, Theodore C. 1982. “On Capturing Oil Rents with a National Excise Tax,” American Economic Review, volume 72, number 1 (March): 194-201.

Bright, Beckey, “Many Americans Are Trimming Travel, But Few Car Pool To Cut Fuel Use,” Wall Street Journal, July 7, 2007.

Caplan, Bryan. 2007. The Myth of the Rational Voter: Why Democracies Choose Bad Policies, Princeton NJ: Princeton University Press.

Izzo, Phil, “Is It time for a New Tax on Energy?” Wall Street Journal, February 9, 2007.

Metcalf, Gilbert E. 2007. “A Green Employment Tax Swap: Using a Carbon Tax to

Finance Payroll Tax Relief,” Policy Brief, The Brookings Institution and the World Resources Institute.

Nordhaus, William. 2007. “Critical Assumptions in the Stern Review on Climate Change,” Science, volume 317, July 13: 201-202. 
Parry, Ian W. H., Margaret Walls, and Winston Harrington. 2007. “Automobile

Externalities and Policies,” Journal of Economic Literature, volume 45, issue 2 (June): 373-399.

Poterba, James M. 1991. “Is the Gasoline Tax Regressive?” Tax Policy and the Economy, volume 5: 145-164.

Stern, Nicholas. 2006. The Economics of Climate Change, Cambridge: Cambridge University Press.

Whaples, Robert. 2006. “Do Economists Agree on Anything? Yes!” The Economists' Voice, volume 3, issue 9. 